\title{
Bush Mango (Irvingia spp.) As an Important Alternative Livelihood Source for the Indigenes of the Korup National Park Communities, South West Cameroon
}

\author{
Gadinga W. Forje ${ }^{1 *}$, Tchamba Martin ${ }^{1}$, Barnabas N. Nfornkah ${ }^{1}$, Chimi C. Djomo², Reeves M. Fokeng ${ }^{3}$ \\ ${ }^{1}$ Department of Forestry, University of Dschang, PO Box. 222, Cameroon \\ ${ }^{2}$ Institute of Agricultural Research for Development (IRAD), Bertoua, PO Box. 203, Cameroon \\ ${ }^{3}$ Department of Geography \& Planning, Faculty of Arts, University of Bamenda, P.O Box. 39, Bambili, Cameroon
}

Corresponding Authors Email: gwforje@gmail.com

https://doi.org/10.18280/eesrj.060401

Received: 8 October 2019

Accepted: 3 December 2019

\section{Keywords:}

bush mango, value chain, protected areas, constraints, livelihood, natural resources, non timber forest products, bush mango exploitation rights

\begin{abstract}
Protected resources continue to suffer illegal exploitation due to inadequate alternative livelihood options to the local populations. This study evaluated bush mango current situation in Korup National Park Communities (KNPCs). Five villages were selected based on high productivity. Focused group discussion was done in each village to identify stakeholders in the bush mango sector. Ninety-four household questionnaires administered to collectors. All collectors exploited rainy season bush mango; 36 (38\%) collectors collected dry season bush mango in farms, $86 \%$ had cultivated dry season bush mango and $54 \%$ rainy season bush mango. Collectors, village traditional councils (VTCs), Cooperative and ordinary buyers constituted primary stakeholder. Households kernel's quantities produced varied (3442 contents) and sold at US \$42.4/content. KNPCs produced 1,658,880 kg kernels and sold for \$ 3,907,584 / harvest season. Salient constraints were: long distances trekked to sites, ant bites, processing accidents, inadequate drying/storage facilities, poor roads and inadequate market information. Improved seedlings with good characteristics (rapid growth rate, large kernels sizes; self-cracking seed shells); fruit/ seed cracking machine; drying ovens; improved roads; and telecommunication networks for market intelligent communication were solicited. Both bush mangoes enhanced livelihoods in KNP and its cultivation will increase sustainable livelihoods source and reduce pressures on protected resources.
\end{abstract}

\section{INTRODUCTION}

The management of natural resources in developing nations is a complex task if we consider the dependency ratio of the local population on the resources and the governance of natural resources [1]. Cameroonians especially the local people in the forest areas strongly rely on NTFPs for their food, medicines, and local construction material [2,3]. Bush mango is an important NTFP whose kernels are popularly used as soup thickener and for slimy consistency of sauces in African cuisine. Recently, research has shown that bush mango kernels can reduce obesity, control appetite, and reduce fat and cholesterol in humans [3]. It has been used for time immemorial for subsistence, income generation, medicine, and wood for construction. Rainy season and dry season bush mangoes are two local forest tree species, economically important for their fruits which are both called "bush mango". Apart from morphological differences, the two species differ in that one produces fruit in the wet season (rainy season bush mango) and the other in the dry season (dry season bush mango) [4]. Collectors, along with many animal species are active agents involved in the efficient rainy season bush mango seed dispersion in the wild, thus increasing the abundance in the natural forests [4].

Bush mango had experienced an increasing market demand in the last twenty years but production is limited to traditional processing techniques and this and other problems have constrained productivity, output and income earned by collectors [3]. Collection and trade of the resource has evolved overtime with more stakeholders getting involved in the business as well as individuals exerting ownership of trees in farmlands acquired from conversion of forest. Rainy season bush mango flowers between February and March and fruits in the rainy season between July and September when it is collected, while dry season bush mango flowers in October and fruits in the dry season between January and March when it is collected [5-7]. Majority of collectors collect rainy season bush mango from the wild or communal lands and very few collected from bush mango plantations [8]. There was need to integrate the bush mango species into different cropping systems in order to reduce pressure on the protected species in the national park [2]. Innovations in favour of modern processing equipment will ensure enhanced income and better life for the producers [9].

This innovation is highly needed because the market and processing accidents were the main constraining factors in the processing of bush mango [10]. A mounted device (machine) for cracking of bush mango, whose performance characteristics showed $100 \%$ efficiency, with kernel breakage estimated at $24 \%$ was produced by Ogunsina et al. [11]. This excellent technology highly solicited for the processing of bush mango is still very scarce and a good number of collectors in the bush mango sector are not aware. Transforming kernels into new products demands a lot of time and effort [12]; poor storage facilities contributed to reducing kernel life span and spoilage of the products within short 
period from production. This precipitates quick transportation and sale of bush mango during lower prices [13]. Bush mango kernel quantities over the last five years have been increasing [13] and its marketing is a female oriented enterprise with about $90 \%$ women involved in the trade [14]. The main determinants of the selling price for bush mango kernels were the cost price of the commodity and transportation cost.

Bush mango value chain in the South West Region was studied by Ewane et al. [15], who established the added value from collections, processing, storage, transformation and marketing. The income made by the different actors involved in the chain was also accessed. Tataw et al. [3] also conducted a similar study on bush mango which they identified the main production zones and market chains in the South West Region. Amongst the production zones identified, were the Takamanda and Korup National Park areas. The studies of Ewane et al. [15] and Tataw et al. [3] did not lay enfaces on conservation of natural resources. Nfornkah et al. [4] examined the bush mango sustainability and indigenous knowledge promoting kernels exploitation and their influence on resource conservation in the Takamanda National Park (TNP) and found that the local people organised themselves through their village traditional councils to create bush mango governance, which enables them resolve conflicts, increase production, ensures sustainability of bush mango. Nfornkah et al. [16] also accessed NTFPs potentials in quantities and income per peak season in the Takamanda National Park Communities (TNPCs). From these two studies carried out by Nfornkah et al. [16] and corroborators, it was noted that more essential information such as: exploitation, marketing, sustainability, indigenous governance, constraints and opportunities of bush mango were meticulously diagnosed; which can be exploited by decision makers to improve policies on conservation and living conditions of riverine people around protected areas. It was important to carry out more of such protected areas to at the end make a holistic judgment and backed it with policies that shall be workable for the benefit of conservation and livelihoods of riverine people.

The Kurop National Park was identified as a high NTFPs production zone [3]. The local people in and around the KNP have led their lives from gathering, hunting and agriculture. Hunting and gathering of NTFPs have been very lucrative in recent decades because of the high economic value, less bulky than agricultural products and high market demand in neighbouring Nigeria. Amongst these gathered NTFPs in the $\mathrm{KNP}$, bush mango (Irvingia spp.) is the most lucrative and highly valued. The Korup National Park (KNP) is struggling to achieve its conservation goals with difficulties due to diverse threats emanating from human activities and unsustainable exploitation of NTFP that renders riverine population vulnerable, pushing them to continue illegal exploitation of protected resources. This pressure has threatened the protected resources in the KNP. The wealth of research across the South West and East Regions of Cameroon on bush mango exploitation, processing, marketing and sustainability leaves out the KNP and environs [2-4, 7]. Whereas a wider assessment of the value, threats and sustainability of bush mango and its contributions to the sustenance of rural livelihoods are important pillars to park management and conservation efforts. It is against this research gap that through a case study analysis of the KNP, the study sought to assess the bush mango value chain, which its promotion shall improve livelihood alternative source for subsistence, income generation, and conservation in KNP. The objectives of this study were set as to:

(1) Identify actors/value chain and types of bush mango exploited;

(2) Assess exploitation techniques and marketing processes;

(3) Identify the constraints and propose solutions for the sustainable exploitation of bush mango in and around KNP.

The paper therefore is an added value to the plethora of research in the theme across the South West Region of Cameroon and adds baseline data towards the sustainable exploitation and management of NTFPs in and around protected areas. This will help in proper design of park management and conservation plans that address the needs and expectations of the forest communities and the sustenance of their livelihood within the context of achieving Sustainable Development Goals (SDGs 1.4, 15.1, 15.2 and 15.9).

\section{MATERIALS AND METHODS}

\subsection{Study area}

This study was carried out in the Korup National Park communities (KNPCs) (Figure 1). The Korup National Park cuts across the Ndian and the Manyu Divisions of the South West Region of Cameroon. It has a surface area of $1269 \mathrm{~km}^{2}$ and shared a long boarder of $25 \mathrm{~km}$ with the Cross River National Park of Nigeria [17]. The soils in the Korup are ferralitic, derived from deep weathering syenite and igneous rocks and strong acidic content [18]. This locality is characterised by a pseudo-equatorial climate with two seasons: a short dry season (November-February) and a long rainy season (March-October). Average rainfall in the dry season is less than $100 \mathrm{~mm} / \mathrm{month}$ and in the rainy season it rises above $1,000 \mathrm{~mm} / \mathrm{month}$ [19] or above $5,000 \mathrm{~mm} /$ year [20]. The temperature varies between $30.2^{\circ}-31.8^{\circ} \mathrm{C}$ throughout the year and the mean annual humidity is $83 \%$. The altitude at the level of Mt. Ekundukundu is $1,075 \mathrm{~m}$. The whole zone is made of a network of rivers as the Ndian, Akpa Yafe (South) and Munaya (North) of the Park [20]. The forest is an evergreen humid dense forest of the Guineo-Congolese type situated in the Atlantic forest sector of the Atlantic Briafran District [20]. This forest vegetation supports large populations of chimpanzee, drill, red-capped mangabey, red-eared monkey, Preuss' red colobus monkey and Preuss' monkey [21]

Using a purposive sampling, five villages: Esukutan, Akwa, Ajaman, Babi and Mbufong (Figure 1) selected from 32 villages within and at the periphery of the KNP (5 villages inside and 27 outlined villages). These communities were selected with the help of the Programme for Sustainable Management of Natural Resources in the South West Region (PSMNR-SWR) based on their high involvement in the exploitation and marketing of bush mango. These communities were issued access right to collect bush mango in the National Park by the Park authority during three months of the peak season (July-September). Assuming that the villages inferred were representative of all 32 villages, and that the proportion of collectors sampled in this study area are a representative of the total collectors of bush mango in the entire KNP communities, quantities and income of bush mango shall be extrapolated to the whole 32 villages. 


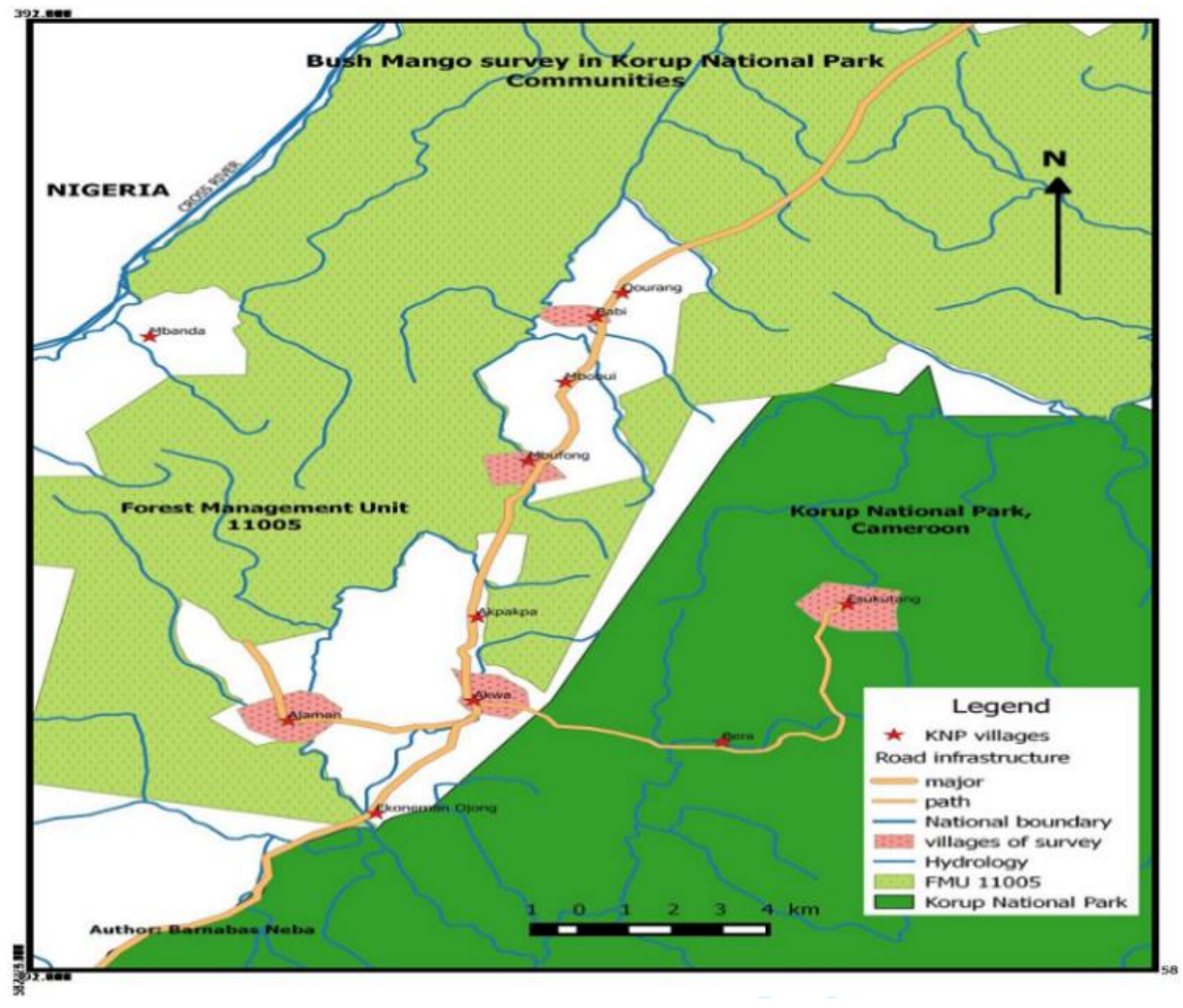

Figure 1. Villages surveyed for bush mango exploitation in KNPCs

\subsection{Field survey}

Field survey was done in five villages (Esukutan, Akwa, Ajaman, Babi and Mbufong) around the KNP. A focussed group discussion was held in each village chosen for this study to identify collectors and other important actors in the bush mango exploitation and marketing processes. In these villages, ninety-four (94) questionnaires were administered each per household exclusively to bush mango collectors of age 25 and more of both sexes. In each village, questionnaires were administered to about $25 \%$ of the entire collectors. The selection of a household for this survey was based on active involvement in the collection of bush mango during this study period. Interviews were granted to the management of the Park authority, 4 ordinary bush mango buyers and 3 Forest resource promotion (FREPROM) cooperative buyers. Interview was also granted to the leader of each village traditional council (VTC). Questionnaires were structured to gather information on types and actors involved with bush mango exploitation processes and marketing; constraints encountered, local remediation and expected solutions to the constraints, and secondary activities in the national park (those illegal activities collectors would do behind bush mango collection). Actors of bush mango considered in this study were those operating within the KNPCs (internal and external). Bush mango value chain in this study was limited within the KNPCs i.e. collection, processing, storage and marketing. The scope of this study was to better understand types of bush mangoes available here that is collection, processing, storage and marketing within the KNPCs. Also, the constraints faced by actors, actual remediation, anticipated solutions and the income made by collectors within the different communities in the KNP were the study concerns. This information gathered with the questionnaires permitted us to propose recommendations which would improve the local people's living condition with the aim to dissuade them from illegal exploitation of the protected resources in the Korup National Park.

\subsection{Data analysis}

Information from questionnaires was keyed into Microsoft excel and analysed with SPSS version 20. QGIS version 2.8.1 was used to produce the map of the study area. Shapiro-wilk test showed our data followed a normal distribution. A parametric test of ANOVA was used to test for the significance levels of the different constraints faced during the exploitation and marketing of Irvingia. Local measuring vessels were calibrated to standard measurements. The exchange rate for Francs CFA to US dollars was 500:1 i.e. $500 \mathrm{~F} \mathrm{CFA}=\$ 1$ at the time of data collection.

\section{RESULTS}

\subsection{Irvingia types and actors involved in exploitation in the KNPC}

\subsubsection{Irvingia types found in KNPC}

Two (2) species of bush mango were found collected, 
processed and marketed in the KNPCs. These species were dry season bush mango (exotic species) and the rainy season bush mango (indigenous species). All 94 respondents were involved in the collection of the rainy season bush mango. About 36 $(38 \%)$ out of 94 respondents were also involved in the collection of dry season bush mango from their farms. About $86 \%$ of the collectors admitted having cultivated dry season bush mango in their farms while about $54 \%$ had also cultivated rainy season bush mango. Bush mango value chain and actors involved within KNPCs. The bush mango value chain in the KNPCs clearly involved all the different stages of exploitation and marketing within the communities. This also involved the key actors in the exploitation and trade in bush mango within these communities. The key actors were collectors, Village traditional councils, cooperative and ordinary buyers and the park service. The value chain is represented in Figure 2. The following actors were identified in the value chain of bush mango sector: (1) Internal actors constituted of (i) collectors who are responsible for collection, processing, storage and sales of bush mango and (ii) village traditional council who regulated collection of bush mango in the communities and resolve related conflicts, and (2) External actors constituted of (i) FREPROM Cooperative: organisation of collectors, registering them, buying their kernels and training registered members on correct measuring scales and vessels; and (ii) Buyers: bought bush mango from collectors in the villages (iii) Park authority: regulated access rights into the National Park for collection via eco-guards.

\subsubsection{Exploitation of bush mango in the KNPC}

The custom of the people forbids the climbing of bush mango trees. So, collection method was gathering under the trees. In our study area, bush mango was collected in two major areas: natural forests (forest management unit (FMU 11005) and the Korup national park) and farm plots. Entry into the National park is forbidden by the Forestry and wildlife law of Cameroon but the indigenes disobeyed this law. Rainy season bush mango was collected in natural forests and farm plots while dry season bush mango was collected strictly in farm plots because there were planted buy owners. About $92 \%$ and $88 \%$ of collectors in Esukutan and Mbufong respectively collected rainy season bush mango in the national park (protected area) because their proximity to the FMU and Park. The low rate $(28 \%)$ of rainy season bush mango collection in farms was because of the limited number of trees in farm plots. In years of low fruiting, collectors move deep into the KNP for collection. This is also associated with poaching of large mammals: elephant, buffalo, chimpanzee, etc. Only indigenes were allowed by the traditional councils to collect rainy season bush mango in the KNPC. An exception was noticed in Mbufong were strangers about $8 \%$ from Akwaya were permitted but after having spent two years in Mbufong. Collectors spent averagely 1-2 days (16\%) respondents, 3-4 days $(57 \%)$ and 5-6 days (27\%) per week in bush mango collection. Collectors identified rainy season bush mango in the natural forests by (1) scent of ripen fruits; (2) information from hunters; (3) sound of fallen fruits; (4) during eru harvesting; (5) long period of experience in the forest; and (6) vocal sounds of different eaters (animals) on the trees. Collection, processing and storage techniques (Table 1) of bush mango were also practiced in the KNPC.

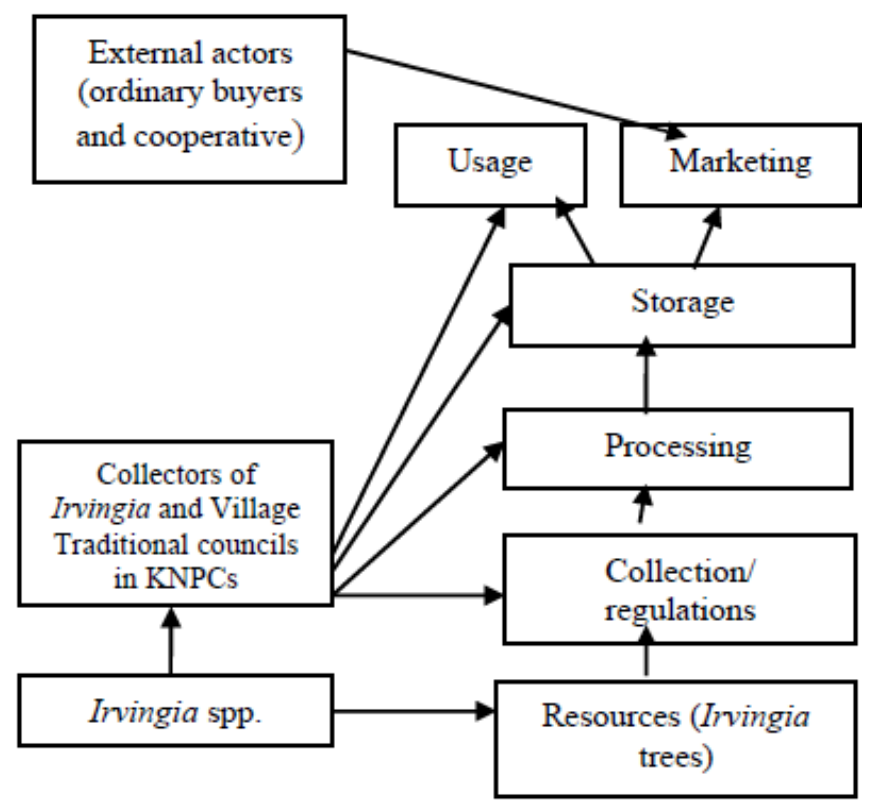

Figure 2. Bush mango value chain in the KNPCs

Table 1. Techniques of collection, processing, drying and storage

\begin{tabular}{|c|c|c|c|}
\hline Stage & $\begin{array}{l}\text { Average } \\
\text { duration }\end{array}$ & Techniques involved & Tools \\
\hline Collection & 3-4 days/week & $\begin{array}{l}\text { Fruit picking under the trees (rainy season bush } \\
\text { mango) and (dry season bush mango) }\end{array}$ & $\begin{array}{l}\text { Hand picking, bags, dresses, } \\
\text { Cutlass, etc. }\end{array}$ \\
\hline & & Fruit splitting of ripen fruits & $\begin{array}{l}\text { Cutlass, Knife, sharpened stick } \\
\text { Stone-stone, Axe-stone, Dig axe- }\end{array}$ \\
\hline Processing & 3-4 days/week & Squeezed rotten fruit-cracked seeds & $\begin{array}{l}\text { Stone-stone, Axe-stone, Dig axe- } \\
\text { stone, Cutlass-stick. }\end{array}$ \\
\hline Drying & 2-3 days/week & $\begin{array}{l}\text { Kernels extraction } \\
\text { Under sunlight on ground around the house, } \\
\text { On top of zinc over fire, on mats in kitchen, } \\
\text { Plastering of seeds on wall }\end{array}$ & $\begin{array}{l}\text { Nails, knifes, etc. } \\
\text { Mats, tarpaulin, bags } \\
\text { Zinc, fork sticks, } \\
\text { walls }\end{array}$ \\
\hline Storage & 3-4 months/year & $\begin{array}{c}\text { Placing un-cracked seeds on barn } \\
\text { On barns } \\
\text { Suspended planks or surfaces }\end{array}$ & $\begin{array}{c}\text { Bags, bamboos, sticks } \\
\text { Bamboos, ropes } \\
\text { Sticks, planks or bamboos, bags. }\end{array}$ \\
\hline
\end{tabular}

\subsection{Marketing of bush mango in the KNPC}

The quality of bush mango kernels determined the selling price in the KNPC. Kernels were graded before buying. (1) Grade A form fruit splitting technique, sun dried; the kernels showed whitish colour, shiny, firm and solid cotyledons. (2) Grade B from fruit splitting or squeezed-cracked seeds, fire or barn dried, with yellowish colour, and solid cotyledons. (3) Grade C obtained from squeezed-cracked seeds, brownishyellow or dark brown in colour due to poor sun light or fire 
during drying; which lead to attack by mould. The cotyledons are weak and dusty and depreciate rapidly within a week or two in storage. Despite the fluctuating prices of bush mango in the KNPC, the price difference between grade A \& B \& C always $\$ 3$ per content (vessel measuring $18 \mathrm{~kg}$ of kernels). The prices offered for dried rainy season bush mango kernels in the rainy season varies from community to community. Those communities that were having easy accessed from Mamfe and Nigeria received high prices for their kernels than areas with difficult accessed. The prices of a content of rainy season bush mango fluctuated in the communities between \$ 34 and \$ 50 . On an average, the highest selling price was in Babi with $\$ 46$, and the lowest selling price in Esukutan with \$ 40. The high price offered in Babi was due to her proximity to Mamfe and easy access, and can be reached there by motor bike. Esukutan received the lowest price (Table 2) because of her enclave nature and distance away from Mamfe and Nigeria.

The study communities produced an income of US $\$ 770,578$ per year from rainy season bush mango. Extrapolating to the full season in the whole KNPCs (one content $\sim 18 \mathrm{~kg}$ ). Each household $(\mathrm{HH})$ produced an average of 38.4 contents (Table 2), it means (38.4 x 18) $691.2 \mathrm{~kg}$ $/ \mathrm{HH} /$ season. For all the 376 collectors active in the 5 selected villages, it means $(691.2$ x 376) $259,891.2 \mathrm{~kg}$ per season for the 5 villages. Extrapolating to all 32 villages, if each village is considered having the same average number of active collectors, it means $((376 / 5) \sim 75$ per village) than in the sampled (the 5 villages), it would mean that a total of ( $75 \times 32)$ 2400 collectors; assuming the 5 villages selected are representative of the total number of villages (regarding bush mango collection), then the total quantity of bush mango kernels harvested from the KNP area (inside and outside KNP in the 32 villages surrounding the KNP) could be estimated to (691.2 x 2400) 1,658,880 kg or almost 1659 tons. For the total income per season, it means $((1,658,880 \mathrm{~kg}$ x $\$ 42.4) / 18 \mathrm{~kg})$ $\$ 3,907,584$ per season per the whole KNP area (32 villages). Two buyers were identified: FREPROM cooperative and ordinary buyers. Most of the household collectors (79\%) sold their kernels to both buyers; $21 \%$ of the households sold to ordinary buyers (13\%) and FREPROM $(8 \%)$.

Table 2. Average quantity of rainy season bush mango kernels exploited and total revenue generated

\begin{tabular}{ccccc}
\hline Villages & $\begin{array}{c}\text { Av. Price per content } \\
(\mathbf{1 8 k g}) \text { in } \mathbf{\text { S US }}\end{array}$ & $\begin{array}{c}\text { Av. Quantity of kernel per household in } \\
\text { contents (18kg) }\end{array}$ & $\begin{array}{c}\text { Total No of contents } \\
\text { per village }\end{array}$ & $\begin{array}{c}\text { Total revenue generated } \\
\text { in \$ US }\end{array}$ \\
\hline Esukutan & 40 & 42 & 4,704 & 188,160 \\
Ajaman & 44 & 39 & 4,056 & 178,464 \\
Akwa & 42 & 41 & 3,649 & 153,258 \\
Mbufong & 40 & 36 & 2,592 & 103,680 \\
Babi & 46 & 34 & 3,196 & 147,016 \\
Mean & $\mathbf{4 2 . 4}$ & $\mathbf{3 8 . 4}$ & IIIIIIIIIIII & IIIIIIIIIIII \\
\hline
\end{tabular}

\subsection{Constraints of bush mango exploitation and indigenous} remediation

\subsubsection{Constraints in bush mango exploitation chain}

Bush mango collection, processing, storage and marketing was flawed with some constraints (Table 3 ) in the KNPC. The statistical test of ANOVA brought out the level of significance of each constraint showing it strength. The strength of each constraint had a consequence in the bush mango value chain.
During collection of rainy season bush mango, long distances to collection points and ants' bites were the salient constraints encountered by collectors. During processing of bush mango injury accidents and lengthy time for processing were recorded as the prominent constraints; during storage, inadequate drying and long length of storage of rainy season bush mango constituted the highest constraints. Finally, in marketing, the greatest constraint was inadequate information on real market price.

Table 3. Constraints encountered in the Irvingia value chain in KNP communities

\begin{tabular}{ccc}
\hline Stage in value chain & constraints & P-value \\
\hline Collection & Animals invasion and attack & $p=0.031$ \\
& Limited ownership of mature bush mango & $p=0.046$ \\
& Long distances to collection points & $p=0.000$ \\
Processing & Climate related problems & $p=0.027$ \\
& Ant bites & $p=0.000$ \\
Storage & Accident during processing & $p=0.000$ \\
& Long length of time frame for processing & $P=0.000$ \\
& Absence of modern processing & $p=0.007$ \\
Marketing & Inadequate drying & $p=0.000$ \\
& limited storage & $p=0.062$ \\
& Length of storage & $p=0.000$ \\
& limited buyers & $p=0.004$ \\
& inadequate information on real market price & $p=0.000$
\end{tabular}

The statistical analyses are significant at 95\% confidence interval. ***p $<0.001$ (highly significant); $* * \mathrm{p}<0.01$ (moderately significant) and $* \mathrm{p}<0.05$ (least significant).

3.3.2 Indigenous remediation to constraints of bush mango exploitation and marketing chains

Bush mango exploitation constraints had some indigenous remediation while anticipating for better and up to date responds to the constraints. These remedial solutions and expectations were identified and proposed in Table 4. 
Table 4. Indigenous remediation methods and expectations

\begin{tabular}{|c|c|c|c|c|}
\hline $\mathbf{N}^{\circ}$ & $\begin{array}{l}\text { Stage of } \\
\text { difficulty }\end{array}$ & Constraints & Indigenous remediation & Indigenous expectations \\
\hline (1) & Collection & $\begin{array}{l}\text { Long distances to collection } \\
\text { points }\end{array}$ & $\begin{array}{l}\text { Making plantations of } I \text {. wombulu and } I \text {. } \\
\text { gabonensis. }\end{array}$ & $\begin{array}{l}\text { ICRAF to domesticate fast } \\
\text { growing and maturing, thick and } \\
\text { heavy kernels of both dry and rainy } \\
\text { season bush mango }\end{array}$ \\
\hline (2) & Processing & $\begin{array}{l}\text { Insects bites/invasion } \\
\text { Accident during processing }\end{array}$ & $\begin{array}{l}\text { Cover body/winnowing of kernels } \\
\text { No remedy yet }\end{array}$ & $\begin{array}{l}\text { Insectrepellents, Atelicpowder etc. } \\
\text { Make available mounted cracking } \\
\text { device for bush mango by } \\
\text { Ogunsina et al. [11]. }\end{array}$ \\
\hline (3) & $\begin{array}{l}\text { Drying } \\
\text { kernels }\end{array}$ & inadequate drying & Local drying (sun, fire, barns etc.). & Drying Ovens. \\
\hline (4) & Storage & $\begin{array}{l}\text { Inadequate and proper storage } \\
\text { facilities, techniques and duration. }\end{array}$ & $\begin{array}{l}\text { Some put pepper, contry onion in kernels } \\
\text { before putting in bags; placed on barns or } \\
\text { suspensions; stored on an average duration of } \\
3-4 \text { months only. Within this duration, they } \\
\text { sun product every after } 2 \text { weeks. }\end{array}$ & $\begin{array}{l}\text { Capacity building on proper } \\
\text { storage and food safety methods. }\end{array}$ \\
\hline (5) & Marketing & $\begin{array}{l}\text { Inadequate information on real } \\
\text { market price; trade by barter } \\
\text { exploitation mafia; lack of } \\
\text { bonuses from FREPROM; and } \\
\text { cheating measuring scales and } \\
\text { units. }\end{array}$ & $\begin{array}{l}\text { No remedy yet on how to get market prices } \\
\text { before selling, FREPROM had not yet paid } \\
\text { bonuses at the time of this study, FREPROM } \\
\text { built capacity of members to detect } \\
\text { corrupt/cheating practices and denounced } \\
\text { them. }\end{array}$ & $\begin{array}{l}\text { Telecommunication networks in } \\
\text { the villages, payment of bonuses to } \\
\text { cooperative members and prohibits } \\
\text { of trade by barter. }\end{array}$ \\
\hline
\end{tabular}

\section{DISCUSSION}

The KNPCs exploited both rainy and dry bush mangoes. The low rate (28\%) of rainy season bush mango collection in farms was because of the limited number of trees in farm plots. About $86 \%$ of the collectors had cultivated dry season bush mango in their farms while about $54 \%$ were involved in the cultivation of rainy season bush mango. This result is supported by the growing importance of rainy season bush mango as a sustainable livelihood NTFP and the added value obtained from it [4]. This also supports the fact that the cultivation of NTFPs in agroforestry plots is a better option to ensure resource availability and enrich smallholders [3, 22]. This cultivation will also give right to ownership; reduce distances to the resources and conflicts resolutions [4]. This result corroborates with those of Tataw et al. [3] on 'forest and on-farm resource availability and market chains in the Southwest Region of Cameroon' that ' $34 \%$ of the total respondents had already collected fruits from their planted trees, which suggests that cultivation is a recent phenomenon'.

This result showed that in years of low fruiting, collectors moved deep in the National Park for collection. This is also associated with poaching of large mammals: elephant, buffalo, chimpanzee, bush pigs etc. This is supported by the reason that collectors do not respect the three months of the memorandum of understanding signed between collectors and Park authority, which give access right to collectors to enter the National Park. The people of Esukutan (inside park), Akwa (proximity to park and FMU) and Ajaman (proximity of FMU) had impression that they have the right of the forest and no one can stop them from hunting. That it was a heritage from their ancestors and have to protect it. The chief of Ajama lamented that when a project is awarded for conservation, the money ends in private pockets leaving the population in agony. The Park management has not enough eco-guards to patrol the entire park and so this part of the park has no control. These results corroborate those of Dupuy [22] on 'collaborative management of protected areas in South West Region' that collectors have user rights to collect NTFPs into the protected areas. The collectors register with the park service and are given access cards to collect within their cluster conservation zone (CCZ) in the park [22]. The study of Nfornkah et al. [16] on 'NTFP, an asset for conservation of TNP' revealed that everyone was free to collect NTFPs provided certain key conditions were respected before and during collection. Tataw et al. [3] reported that in Takamanda and Korup National Park areas collectors has ownership over stands within the permanent use zones.

The results of this study identified one technique for bush mango collection in the study area being the gathering of fruits (fruit picking) only under the trees. Climbing up bush mango trees was prohibited to all collectors by the Village Traditional Council. This result is contrary to those of Ayuk et al. [23] on 'Uses, management and economic potential of bush mafigurengo in the humid lowlands of Cameroon' where two techniques (fruit gathering and tree climbing) of bush mango collection were identified. Collectors spent averagely 3-4 days in collection and processing of rainy season bush mango. Drying took averagely 2-3 days on sunny days, while storage took averagely 3-4 months before selling of kernels. This different time intervals permitted the collectors to maximised bush mango exploitation before marketing. It was observed that collectors who spent these intervals well produced great quality and quantities of bush mango per household. They often produced grade A and B. This also affects positively the household's income and livelihood.

This result showed villages inside the Park (Esukutan) or closer the natural forest (Ajaman) producing more kernels (42 and 39 contents respectively) than those out of the Park vicinity. This could be explained by the fact that the natural forest (FMU and KNP) have more bush mango resources than in the other villages. This was also supported by the free access right given to collectors in and around the KNP to collect in the Park. These communities benefit more than the others because of the law that only indigenes collect bush mango in their villages. This gave more resources to these villages beside or inside the park to harvest more. On the contrary, the market prices in these communities fall. This was caused by 
poor access and long distances to transport kernels from here to Mamfe. This result corroborated with those of Tataw et al. [3], who found that in remote communities such as those living within and around Korup National Park, poor accessibility translated in lower prices of bush mango. Also, Nfornkah et al. [16] found out that prices of NTFPs varied from village to the next depending on the accessibility or nearness to road sides or nearness to Nigeria, the main NTFPs market in West Africa. Despite these low prices, this deficit was compensated with high quantities of kernels produced thus recording the highest income in the sales (Esukutan $=188,160$ and Ajaman $=$ $178,464)$ in US dollars.

This study depicted a number of exploitation constraints such as long distances to collection points and ant bites during collection, accidents during processing and long time frame in processing, inadequate drying and long period of storage and inadequate information on real market prices. This constraint really hampered the exploitation and marketing for bush mango in KNPCs. These constraints were similar to those of Chah et al. [8] in Enugu Nigeria, who identified high production costs, high pests and rodents' infestation of products and processing sites, poor and inadequate technological resources in harvesting and processing, poor storage facilities/short shelf life span of the kernels, transportation and bulky nature of bush mango fruits, and unstoppable/unguaranteed price of bush mango.

Despite these constraints, the indigenous people succeeded in dealing with them in their own ways. They had expectations which can better solve these major constraints, thus improving on their bush mango cultivation, exploitations and marketing. They expected improved species of both bush mango species with characteristic features such as fast growth to maturity, large and thick kernels and self-explosive seeds at majority from International Centre for Research in Agroforestry (ICRAF). Recommended seed processing machine, drying oven, capacity building and telecommunication network to facilitating communication within market agents. These results Concorde with those of Nfornkah et al. [16] who found similar anticipations from NTFPs collectors in the TNPCs.

\section{CONCLUSION}

Bush mango resources (rainy and dry season bush mangoes) were found in the KNPCs, with rainy season bush mango very much abundant and exploited mostly from the wild. Actors of this resource were external (park service and buyers) and internal (collectors and village traditional councils). More bush mango was collected from the natural forests (protected area), leading to secondary activities as poaching of large mammals. Because of the highly beneficial value of bush mango as food, medicine, timber and income generation among others to the collectors, local denizens in the forest's zones are beginning to establish mixed agroforestry plantations to ensure sustainable production of bush mango in KNPCs and Cameroon. Enclave communities in and around the natural forests produced more bush mango kernels but sold at lower prices due to difficult access. The entire KNPCs produced $1,658,880 \mathrm{~kg}$ or almost 1659 tons of bush mango kernels per peak season. For the total income per season, $\$ 3,907,584$ was estimated in the communities. Exploitation and marketing of bush mango was flawed with several constraints needing rescue for the improvement of bush mango sector here. Based on the constraints identified in this study we recommend the cultivation and domestication of both bush mango species outside of the natural forests to increase economic returns in both seasons and reduce pressure on protected resources. Some research gaps for further investigation on the theme include: -

(1) Inventory of the spatial extent of domestication of bush mango and its contributions to household income;

(2) Investigation of the link between bush mango exploitation, poaching and loss of large mammals within forests and protected areas;

(3) Also, the link between bush mango exploitation tracks in the forest and forest loss;

(4) Relationships between land ownership rights, bush mango exploitation rights and conflicts in and around exploitation zones.

\section{ACKNOWLEDGMENT}

We thank the Programme for Sustainable Management of Natural Resources, South West Region Cameroon (PSMNRSWR) for their financial and technical support.

\section{REFERENCES}

[1] Tabue, M.R., Chimi, D.C., Djanteng, S.P., Nanfack, A.E., Noiha, N.V., Barnabas, N.N., Forbi, P.F., Kabelong, B.L., Zekeng, J.C., Awono, N.J., Wabo, P.F., Ngoma, L.R., Zapfack, L. (2018). Indigenous knowledge as a tool for wildlife conservation in the dja biosphere reserve, Cameroon. International Journal of Social Science and Humanities Research, 6(4): 148-156.

[2] Awono, A., Djouguep, A., Zapfack, L., Ndoye, O. (2009). The potential of Irvingia gabonensis: Can it contributes to the improvement of the livelihoods of producers in Southern Cameroon? International Journal of Social Forestry, 2(1): 67-85.

[3] Tataw, O., Nkongho, R.N., Awono, A., Levang, P. (2017). Bush mango (Irvingiaspp.): Forest and on-farm resource availability and market chains in the Southwest Region of Cameroon. Forests, Trees and Livelihoods, 26(3):

170-182. https://doi.org/10.1080/14728028.2017.1283250

[4] Nfornkah, B.N., Tchamba, M., Chimi, D.C., Gadinga, W., Mairong, F. (2018). Indigenous knowledge on Irvingia gabonensis (bush mango) sustainability in the Takamanda National Park (TNP) communities, South West Cameroon. Forests, Trees and Livelihoods, 27(4): 257-263. https://doi.org/10.1080/14728028.2018.1512423

[5] Franzel, S., Jaenicke, H., Janssen, W. (1996). Choosing the right trees: Setting priorities for multipurpose tree improvement. ISNAR Research Report 8, p. 87.

[6] Okafor, J.C., Ujor, G. (1997). Varietal differences in Irvingia gabonensis. Bush mango and close relatives. Proceedings of a West African Collection Workshop held in Ibadan, Nigeria. Ladipo, D.O. and Boland, D. (Eds.), ICRAF, Nairobi, Kenya, pp. 5-10.

[7] Elah, M.E. (2010). Markets and market chain analysis for bush mango (Irvingiasp.), in the South West and East Regions of Cameroon. Master's thesis, Department of Geology and Environmental Science, Faculty of Science, 
University of Buea, p. 144.

[8] Chah, J.M., Ani, N.A., Irohibe, J.I., Agwu, A.E. (2014). Exploitation of bush mango (Irvingia wombolu and Irvingia gabonensis) among rural household in Enugu State, Nigeria. Journal of Agricultural Extension, 18(2).

[9] Ugwumba, C.O.A., Wilcox, G.I., Aniaku, C.O. (2013) Economics of Irvingia excelsa "agbono" kernel production in Nsukka local government area of Enugu state, Nigeria. Journal of Agricultural and Biological Science, 8(3): 399-404.

[10] Unaeze, H.C., Henry-Unaeze, H.N. (2014). Socioeconomic determinants of the quality of Irvingia gabonensisharvested by rural dwellers in Sagbama local government area of Bayelsa state, Nigeria. Egyptian Journal of Biology, 16: 39-44. https://doi.org/10.4314/ejb.v16i1.5

[11] Ogunsina, B.S., Koya, O.A., Adeosun, O.O. (2008). A table mounted device for cracking Dika nut (Irvingia gabonensis). Agricultural Engineering International: The CIGR E-Journal. Manuscript PM 08011.

[12] Awono, A., Djouguep, A., Zapfack, L., Ndoye, O. (2009). The potential of Irvingia gabonensis: Can it contributes to the improvement of the livelihoods of producers in southern Cameroon? International Journal of Social Forestry, 2(1): 67-85.

[13] Babalola, F.D., Agbeja, B.O. (2009). Marketing of Irvingia spp (Bush mango) in southwest Nigeria: prospects and challenges. Journal of Agriculture and Biological Sciences, 5(6): 944-953.

[14] Agbelade, A.D., Onyekwelu, J.C. (2013). Poverty alleviation through optimizing the marketing of garcinia kola and Irvingia gabonensis in Ondo State, Nigeria. ISRN Forestry, Volume 2013, Article ID 376247, 5 pages. http://dx.doi.org/10.1155/2013/376247

[15] Ewane, M., Ingram, V., Awono, A. (2010). Market chain baseline for Bush Mango (Irvingia spp.) in the Southwest and Eastern Regions of Cameroon. Center for International Forestry Research, 117 pages.

[16] Nfornkah, B.N., Gadinga, W., Tchamba, M., Mairong, F.N., Chimi, D.C. (Submitted). Non Timber Forest
Products; an asset to the Conservation of Takamanda National Park of Cameroon. Forests, Trees and Livelihoods.

[17] Takoyoh, C.E. (2009). The Dilemma of Integrated Conservation and Development in the Korup National Park, Cameroon. PhD Dissertation, University of Rheinischen Friedrich-Wilhelms, 298 pages.

[18] Hawkins, P., Brunt, M. (1965). The soils and ecology of West Cameroon. Report to the Government of Cameroon. 2 vols. FAO Expanded Program of Technical Assistance No.2083. Food and Agricultural Organisation, Rome.

[19] Zimmermann, L. (2000). A comparative study of growth and mortality of trees in caesalp dominated lowland African rainforest at Korup, Cameroon. Quoted in: A management plan for Korup National Park and its peripheral zone, 2003-2007, Ministry of Environment and Forest, Cameroon

[20] Noiha, N.V., Zapfack, L., Sonke, B., Achoundong, G., Kengne, O.C. (2010). Distribution et richesse taxonomiques des épiphytes de quelques phorophytes au Parc national de Korup (Cameroun). International Journal of Environmental Studies, 67(1): 51-61. https://doi.org/10.1080/00207230903465320

[21] Oates, J.F. (1996). African Primates: Status Survey and Conservation Action Plan. Revised Edition, IUCN, Gland, Switzerland, 87 pages. https://doi.org/10.2305/IUCN.CH.1996.SSC-AP.4.en

[22] Dupuy, J. (2015). Collaborative management of protected areas, PSMNR-SWR approach and concepts. Programme for Sustainable Management of Natural Resources, South West Region (PSMNR-SWR), Buea, Cameroon

[23] Ayuk, E.T., Duguma, B., Franzel, S., Kengue, J., Mollet, M., Tiki-Manga, T., Zenkeng, P. (1999). Uses, management and economic potential of Irvingia gabonensis in the humid lowlands of Cameroon. Forest Ecology and Management, 113(1): 1-9. https://doi.org/10.1016/S0378-1127(98)00323-5 